\title{
Adenosine receptor agonists: synthesis and binding affinity of 2- (aryl)alkylthioadenosine derivatives
}

\author{
Rosaria Volpini, Stefano Costanzi, Catia Lambertucci, Floriana R. Portino, Sara Taffi, \\ Sauro Vittori, Jeff A. Zablocki॰ ${ }^{\circ}$ Karl-Norbert Klotz ${ }^{\S}$, and Gloria Cristalli* \\ Dipartimento di Scienze Chimiche, Università di Camerino, I-62032 Camerino (MC), Italy, \\ Department of Bioorganic Chemistry, CV Therapeutics, inc. 3172 Porter Drive, Palo Alto, CA \\ 94304 USA, and \\ ${ }^{\S}$ Institut für Pharmakologie und Toxikologie, Universität of Würzburg, D-97078 Würzburg, \\ Germany \\ E-mail: gloria.cristalli@unicam.it
}

In honor of Prof. Vincenzo Tortorella in the occasion of his "Fuori Ruolo" status (received 30 Dec 03; accepted 13 Apr 04; published on the web 15 Apr 04)

\begin{abstract}
The synthesis of a new series of 2-(aryl)alkylthio derivatives of N-ethylcarboxamido adenosine (NECA) is described, in comparison with the corresponding derivatives of adenosine. Binding studies $\left(A_{1}, A_{2 A}\right.$, and $\left.A_{3}\right)$ and adenylyl cyclase activity $\left(A_{2 B}\right)$ at human adenosine receptor subtypes stably transfected in Chinese hamster ovary $(\mathrm{CHO})$ cells showed that the 2(aryl)alkylthioadenosine derivatives are more potent than the corresponding NECA derivatives at $\mathrm{A}_{1}$ receptors, while the NECA derivatives possess highest affinity at both $\mathrm{A}_{2 \mathrm{~A}}$ and $\mathrm{A}_{3}$ receptors. Thus, the 2-(1-pentyl)thioadenosine (7) with a $\mathrm{K}_{\mathrm{i}} \mathrm{A}_{1}=91 \mathrm{nM}$, the 2-phenylethylthioNECA (18) with a $\mathrm{K}_{\mathrm{i}} \mathrm{A}_{2 \mathrm{~A}}=24 \mathrm{nM}$, and the 2-phenylmethylthioadenosine (11) with a $\mathrm{K}_{\mathrm{i}} \mathrm{A}_{3}=68 \mathrm{nM}$, could be useful tools to be modificated in order to find very potent and selective agonists for the human adenosine receptor subtypes.
\end{abstract}

Keywords: Adenosine receptors, adenosine receptor agonists, NECA derivatives, adenosine derivatives, (aryl)alkylthioadenosine derivatives

\section{Introduction}

Adenosine (Ado, 1) is a naturally-occurring nucleoside which is reported to modulate a variety of physiological and pathophysiological processes through the interaction with at least for subtypes of a family of cell-surface G-protein-coupled receptors. ${ }^{1-3}$ These four adenosine receptors (ARs), named $A_{1}, A_{2 A}, A_{2 B}$, and $A_{3}$, have widespread tissue distribution and are often co-expressed in the same cell type. ${ }^{4}$ 
The search for potent and selective $\mathrm{A}_{2 \mathrm{~A}}$ adenosine receptor agonists has been a target of medicinal chemists, since it is now well known that the coronary vasodilation induced by Ado in different species is mediated by activation of $\mathrm{A}_{2 \mathrm{~A}} \mathrm{AR}$ and a compound capable of producing coronary vasodilation through activation of $\mathrm{A}_{2 \mathrm{~A}} \mathrm{AR}$, but that is devoid of $\mathrm{A}_{1}$ - and $\mathrm{A}_{3}$-agonist activity would have advantage over Ado for use in myocardial perfusion imaging studies. Other potential therapeutic applications of selective $\mathrm{A}_{2 \mathrm{~A}} \mathrm{AR}$ agonists are as anti-aggregatory, antiinflammatory, anti-psychotic, and anti-Huntington's disease agents. ${ }^{5}$

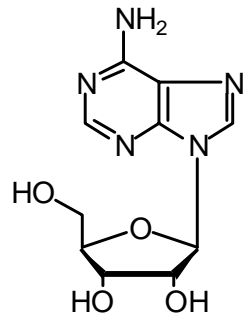

1, Ado

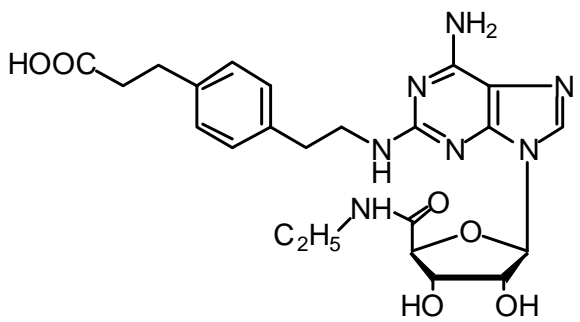

3, CGS 21680

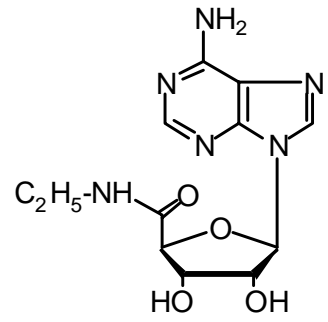

2, NECA

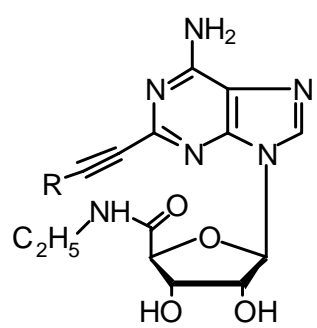

4, $\mathrm{R}=-\mathrm{C}_{4} \mathrm{H}_{9}$, HENECA

5, $\mathrm{R}=-\mathrm{CH}(\mathrm{OH}) \mathrm{C}_{5} \mathrm{H}_{6}$, PHPNECA

\section{Figure 1}

A series of 2-amino, 2-alkoxy, 2-alkythio-, 2-alkynyl-, and 2-alkenyl-derivatives of adenosine and N-ethylcarboxamidoadenosine (NECA, 2) ${ }^{6}$ have been synthesized and tested mainly on different models of rat $\mathrm{A}_{1}$ and $\mathrm{A}_{2 \mathrm{~A}}$ receptor subtypes. From these studies some ligands, such as CGS 21680 (3), 2-(1-hexyn-1-yl)-5'-N-ethylcarboxamidoadenosine (HENECA, 4), and 2-(3-hydroxy-3-phenyl-1-propyn-1-yl)-5'-N-ethylcarboxamidoadenosine (PHPNECA, 5), showed to possess high $A_{2 A}$ affinity combined, in some cases, with good $A_{2 A}$ vs $A_{1}$ selectivity. More detailed characterization of these ligands at the four cloned human adenosine receptor subtypes revealed that none of the prototypical adenosine receptor agonists exhibits at the same time high affinity and selectivity for the human $\mathrm{A}_{2 \mathrm{~A}} \mathrm{AR}$ subtype. Both NECA and CGS 21680, which are available as radioligands for this subtype, have lower affinity at human than at rat receptor. The 2-alkynylNECA derivatives HENECA and PHPNECA showed high affinity also at human $\mathrm{A}_{3}$ receptors. In particular, (S)-PHPNECA displayed $\mathrm{K}_{\mathrm{i}} \mathrm{S}$ in the low nanomolar range at $\mathrm{A}_{1}, \mathrm{~A}_{2 \mathrm{~A}}$, and $\mathrm{A}_{3}$ subtypes and an $\mathrm{EC}_{50}$ of $200 \mathrm{nM}$ at human $\mathrm{A}_{2 \mathrm{~B}}$ receptor. ${ }^{7}$

Further structure-activity relationship studies, carried out often only at $A_{1}$ and $A_{2 A}$ receptor subtypes, had anyhow defined important features of the recognition sites for ARs agonists. The 
adenine ring could be substituted at the 2-position improving $\mathrm{A}_{2} \mathrm{AR}$ selectivity and monosubstitution on the $\mathrm{N}^{6}$-amino group was tolerated, particularly in the case of $\mathrm{A}_{1} \mathrm{AR}$. Substitution at both $\mathrm{C} 2$ and $\mathrm{N}^{6}$ generally does not have additive effects on the $\mathrm{A}_{2} / \mathrm{A}_{1}$ affinity ratio. Combination of substitutions at the 2-position of adenosine and replacing of $-\mathrm{CH}_{2} \mathrm{OH}$ with CONHR usually increased $A_{2}$ vs $A_{1}$ selectivity. On the other hand, the effects on affinity at $A_{1}$ and $\mathrm{A}_{2}$ receptors of concurrent $\mathrm{N}^{6}$ and $\mathrm{C}^{5}$ ' modifications, leading to $\mathrm{N}^{6}$-substituted $\mathrm{N}$ alkyladenosine-5' -uronamides, resulted to be less than additive. ${ }^{7}$

On this basis the synthesis of a new series of 2-(aryl)alkylthio derivatives of NECA was designed to improve the $\mathrm{A}_{2 \mathrm{~A}}$ affinity and selectivity of 2-(aryl)alkylthioadenosines which were reported to possess coronary vasodilating activity ${ }^{8,9}$ and platelet aggregation inhibitory activity. ${ }^{10,11}$

\section{Chemistry}

The synthesis of several 2-(aryl)alkylthio derivatives of adenosine was previously accomplished by the opening-closure method, firstly reported by Kikugawa and Suehido in $1975 .{ }^{12}$ Unfortunately, this procedure was unsuccessful in the case of 2-(aryl)alkylthio derivatives of NECA, owing to the basic condition and the high temperature used in the opening step.

Alternatively, a new synthesis has been performed by reacting 2-iodoadenosine $(6)^{12}$ and 2iodoNECA (14) ${ }^{14-16}$ with the appropriate mercaptans in dry DMF at $120{ }^{\circ} \mathrm{C}$ using potassium carbonate as a catalyst (Scheme 1 and Table 1).

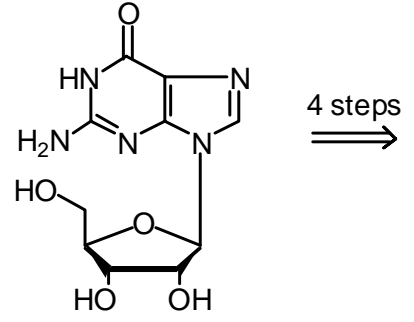

Guanosine

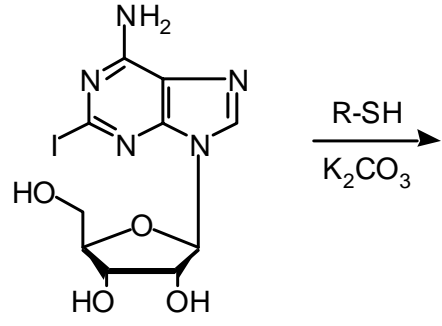

6, 2-iodoAdo

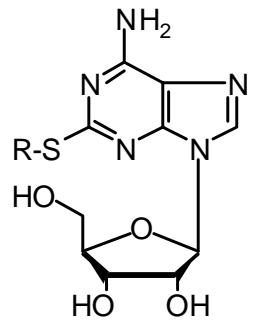

7-13

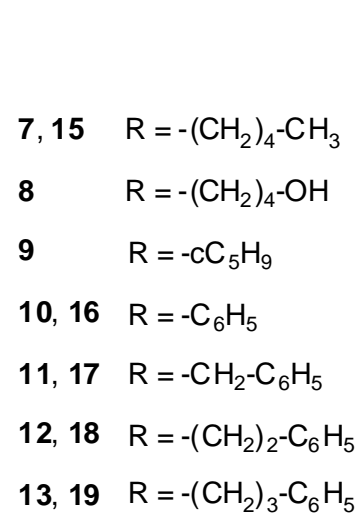

13, $19 \mathrm{R}=-\left(\mathrm{CH}_{2}\right)_{3}-\mathrm{C}_{6} \mathrm{H}_{5}$

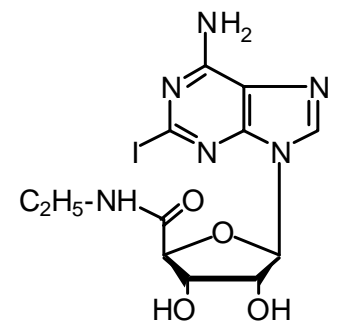

14, 2-iodoNECA

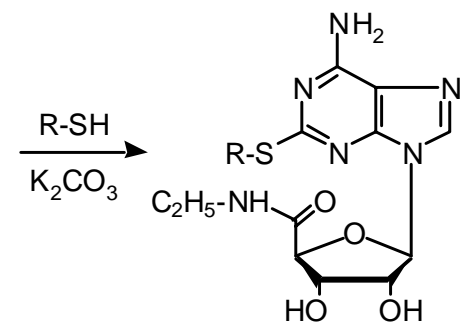

15-19

\section{Scheme 1}


Table 1. Preparation of compounds reported in Scheme 1

\begin{tabular}{|c|c|c|c|c|c|}
\hline Compd no. & $\mathrm{R}$ & Time (h) & Chromatography solvent & Yield \% & $\mathrm{mp}\left({ }^{\circ} \mathrm{C}\right)$ \\
\hline 7 & $\begin{array}{c}\mathrm{CH}_{2} \mathrm{CH}_{2} \mathrm{CH}_{2} \mathrm{CH}_{2} \mathrm{C} \\
\mathrm{H}_{3}\end{array}$ & 20 & $\begin{array}{c}\mathrm{CHCl}_{3}-\mathrm{CH}_{3} \mathrm{OH}-\mathrm{cC}_{6} \mathrm{H}_{12} \\
(76: 14: 10)\end{array}$ & 32 & $\begin{array}{c}177 \mathrm{dec} \\
\text { lit } 148-151\end{array}$ \\
\hline 8 & $\begin{array}{c}\mathrm{CH}_{2} \mathrm{CH}_{2} \mathrm{CH}_{2} \mathrm{CH}_{2} \mathrm{O} \\
\mathrm{H}\end{array}$ & 16 & $\begin{array}{c}\mathrm{CHCl}_{3}-\mathrm{CH}_{3} \mathrm{OH}-\mathrm{cC}_{6} \mathrm{H}_{12} \\
(72: 18: 10)\end{array}$ & 34 & $88-90$ \\
\hline 9 & $\mathrm{cC}_{5} \mathrm{H}_{9}$ & 20 & $\begin{array}{c}\mathrm{CHCl}_{3}-\mathrm{CH}_{3} \mathrm{OH}-\mathrm{cC}_{6} \mathrm{H}_{12} \\
(80: 14: 6)\end{array}$ & 38 & $\begin{array}{c}213 \mathrm{dec} \\
\text { lit } 223-225\end{array}$ \\
\hline 10 & $\mathrm{C}_{6} \mathrm{H}_{5}$ & 20 & $\begin{array}{c}\mathrm{CHCl}_{3}-\mathrm{CH}_{3} \mathrm{OH} \\
(88: 12)\end{array}$ & 40 & $\begin{aligned} & 137-139 \\
& \text { lit } 125-126\end{aligned}$ \\
\hline 11 & $\mathrm{CH}_{2} \mathrm{C}_{6} \mathrm{H}_{5}$ & 20 & $\begin{array}{c}\mathrm{CHCl}_{3}-\mathrm{CH}_{3} \mathrm{OH}-\mathrm{cC}_{6} \mathrm{H}_{12} \\
(75: 15: 10)\end{array}$ & 63 & $\begin{array}{l}158 \mathrm{dec} \\
\text { lit } 158\end{array}$ \\
\hline 12 & $\mathrm{CH}_{2} \mathrm{CH}_{2} \mathrm{C}_{6} \mathrm{H}_{5}$ & 16 & $\begin{array}{c}\mathrm{CHCl}_{3}-\mathrm{CH}_{3} \mathrm{OH}-\mathrm{cC}_{6} \mathrm{H}_{12} \\
(77: 13: 10)\end{array}$ & 50 & $205 \mathrm{dec}$ \\
\hline 13 & $\mathrm{CH}_{2} \mathrm{CH}_{2} \mathrm{CH}_{2} \mathrm{C}_{6} \mathrm{H}_{5}$ & 16 & $\begin{array}{c}\mathrm{CHCl}_{3}-\mathrm{CH}_{3} \mathrm{OH}-\mathrm{cC}_{6} \mathrm{H}_{12} \\
(78: 12: 10)\end{array}$ & 37 & $92-95$ \\
\hline 15 & $\begin{array}{c}\mathrm{CH}_{2} \mathrm{CH}_{2} \mathrm{CH}_{2} \mathrm{CH}_{2} \mathrm{C} \\
\mathrm{H}_{3}\end{array}$ & 36 & $\begin{array}{c}\mathrm{CHCl}_{3}-\mathrm{CH}_{3} \mathrm{OH}-\mathrm{cC}_{6} \mathrm{H}_{12} \\
(80: 10: 10)\end{array}$ & 11 & $>270 \mathrm{dec}$ \\
\hline 16 & $\mathrm{C}_{6} \mathrm{H}_{5}$ & 6 & $\begin{array}{c}\mathrm{CHCl}_{3}-\mathrm{CH}_{3} \mathrm{OH}-\mathrm{cC}_{6} \mathrm{H}_{12} \\
(80: 10: 10)\end{array}$ & 46 & $122-125$ \\
\hline 17 & $\mathrm{CH}_{2} \mathrm{C}_{6} \mathrm{H}_{5}$ & 6 & $\begin{array}{c}\mathrm{CHCl}_{3}-\mathrm{CH}_{3} \mathrm{OH}-\mathrm{cC}_{6} \mathrm{H}_{12} \\
(80: 10: 10)\end{array}$ & 78 & $245 \mathrm{dec}$ \\
\hline 18 & $\mathrm{CH}_{2} \mathrm{CH}_{2} \mathrm{C}_{6} \mathrm{H}_{5}$ & 6 & $\begin{array}{c}\mathrm{CHCl}_{3}-\mathrm{CH}_{3} \mathrm{OH}-\mathrm{cC}_{6} \mathrm{H}_{12} \\
(80: 10: 10)\end{array}$ & 57 & $97-99$ \\
\hline 19 & $\mathrm{CH}_{2} \mathrm{CH}_{2} \mathrm{CH}_{2} \mathrm{C}_{6} \mathrm{H}_{5}$ & 16 & $\begin{array}{c}\mathrm{CHCl}_{3}-\mathrm{CH}_{3} \mathrm{OH} \\
(90: 10)\end{array}$ & 31 & $185-188$ \\
\hline
\end{tabular}

\section{Biological Results and Discussion}

All the compounds were evaluated at the human recombinant adenosine receptors, stably transfected into Chinese hamster ovary $(\mathrm{CHO})$ cells, utilizing radioligand binding studies $\left(\mathrm{A}_{1}\right.$, $\left.A_{2 A}, A_{3}\right)$ or adenylyl cyclase activity assay $\left(A_{2 B}\right)$. Receptor binding affinity was determined using $\left[{ }^{3} \mathrm{H}\right] \mathrm{CCPA}$ (2-chloro- $\mathrm{N}^{6}$-cyclopentyladenosine) as radioligand for $\mathrm{A}_{1}$ receptors, whereas $\left[{ }^{3} \mathrm{H}\right]$ NECA was used for the $A_{2 A}$ and $A_{3}$ subtypes $\left(K_{i} ; n M\right)$. The relative potencies of these compounds for the $A_{2 B}$ subtype were measured by evaluating TABLE 2. Affinities of adenosine and NECA derivatives in radioligand binding assays at human $A_{1}, A_{2 A}$, and $A_{3}$ adenosine receptors and effects on adenylyl cyclase activity at human $\mathrm{A}_{2 \mathrm{~B}}$ adenosine receptor. 


\begin{tabular}{|c|c|c|c|c|c|}
\hline & & \multicolumn{4}{|c|}{$\mathrm{K}_{\mathrm{i}}$ or $\mathrm{EC}_{50}, \mathrm{nM}$} \\
\hline Cpd & $\mathrm{R}$ & $\mathrm{K}_{\mathrm{i}}\left(\mathrm{A}_{1}\right)^{\mathrm{a}}$ & $\mathrm{K}_{\mathrm{i}}\left(\mathrm{A}_{2 \mathrm{~A}}\right)^{\mathrm{b}}$ & $\mathrm{EC}_{50}\left(\mathrm{~A}_{2 \mathrm{~B}}\right)^{\mathrm{c}}$ & $\mathrm{K}_{\mathrm{i}}\left(\mathrm{A}_{3}\right)^{\mathrm{d}}$ \\
\hline $\begin{array}{c}2 \\
\text { NECA }\end{array}$ & & $\begin{array}{c}14 \\
(16-28)\end{array}$ & $\begin{array}{c}20 \\
(12-35)\end{array}$ & $\begin{array}{c}2,400 \\
(1,900-3,000)\end{array}$ & $\begin{array}{c}6.2 \\
(3.5-11)\end{array}$ \\
\hline $\begin{array}{c}3 \\
\text { CGS } 21680\end{array}$ & & $\begin{array}{c}289 \\
(232-361)\end{array}$ & $\begin{array}{c}27 \\
(12-59)\end{array}$ & $\begin{array}{c}89 \mu \mathrm{M} \\
(56-141)\end{array}$ & $\begin{array}{c}67 \\
(50-90)\end{array}$ \\
\hline $\begin{array}{c}\mathbf{4} \\
\text { HENECA }\end{array}$ & & $\begin{array}{c}60 \\
(50-72)\end{array}$ & $\begin{array}{c}6.4 \\
(3.8-11)\end{array}$ & $\begin{array}{c}6,100 \\
(4,000-9,300)\end{array}$ & $\begin{array}{c}2.4 \\
(2.0-2.9)\end{array}$ \\
\hline $\begin{array}{c}\mathbf{5} \\
\text { PHPNECA }\end{array}$ & & $\begin{array}{c}2.7 \\
(1.7-4.1)\end{array}$ & $\begin{array}{c}3.1 \\
(2.4-3.9)\end{array}$ & $\begin{array}{c}1,100 \\
(470-2,600)\end{array}$ & $\begin{array}{c}0.42 \\
(0.17-1.0)\end{array}$ \\
\hline 7 & $\mathrm{CH}_{3}-\left(\mathrm{CH}_{2}\right)_{4^{-}}$ & $\begin{array}{c}91 \\
(83-99)\end{array}$ & $\begin{array}{c}1,370 \\
(993-1,890)\end{array}$ & $>100 \mu \mathrm{M}$ & $\begin{array}{c}365 \\
(285-467)\end{array}$ \\
\hline 15 & $\mathrm{CH}_{3}-\left(\mathrm{CH}_{2}\right)_{4^{-}}$ & $\begin{array}{c}2,400 \\
(2,150-2,690)\end{array}$ & $\begin{array}{c}4,360 \\
(3,840-4,950)\end{array}$ & $>100 \mu \mathrm{M}$ & $\begin{array}{c}1,490 \\
(1,270-1,740)\end{array}$ \\
\hline 8 & $\mathrm{HO}-\left(\mathrm{CH}_{2}\right)_{4-}$ & $\begin{array}{c}451 \\
(427-477)\end{array}$ & $\begin{array}{c}3,130 \\
(2,920-3,360)\end{array}$ & $>100 \mu \mathrm{M}$ & $\begin{array}{c}1,030 \\
(837-1,260)\end{array}$ \\
\hline 9 & $\mathrm{cC}_{5} \mathrm{H}_{9^{-}}$ & $\begin{array}{c}583 \\
(498-682)\end{array}$ & $\begin{array}{c}418 \\
(318-685)\end{array}$ & $>100 \mu \mathrm{M}$ & $\begin{array}{c}843 \\
(610-1,170)\end{array}$ \\
\hline 10 & $\mathrm{C}_{6} \mathrm{H}_{5^{-}}$ & $\begin{array}{c}611 \\
(517-722)\end{array}$ & $\begin{array}{c}990 \\
(829-1,180)\end{array}$ & $>100 \mu \mathrm{M}$ & $\begin{array}{c}669 \\
(563-794)\end{array}$ \\
\hline 16 & $\mathrm{C}_{6} \mathrm{H}_{5^{-}}$ & $\begin{array}{c}1,010 \\
(937-1,100)\end{array}$ & $\begin{array}{c}1,580 \\
(602-4,170)\end{array}$ & $>100 \mu \mathrm{M}$ & $\begin{array}{c}182 \\
(144-230)\end{array}$ \\
\hline 11 & $\mathrm{C}_{6} \mathrm{H}_{5}-\mathrm{CH}_{2}-$ & $\begin{array}{c}304 \\
(260-354)\end{array}$ & $\begin{array}{c}1,510 \\
1,260-1,810)\end{array}$ & $>100 \mu \mathrm{M}$ & $\begin{array}{c}68 \\
(54-85)\end{array}$ \\
\hline 17 & $\mathrm{C}_{6} \mathrm{H}_{5}-\mathrm{CH}_{2-}$ & $\begin{array}{c}480 \\
(400-575)\end{array}$ & $\begin{array}{c}615 \\
(368-1,028)\end{array}$ & $>100 \mu \mathrm{M}$ & $\begin{array}{c}142 \\
(115-175)\end{array}$ \\
\hline 12 & $\mathrm{C}_{6} \mathrm{H}_{5^{-}}\left(\mathrm{CH}_{2}\right)_{2^{-}}$ & $\begin{array}{c}99 \\
(85-115)\end{array}$ & $\begin{array}{c}85 \\
(39-185)\end{array}$ & $>100 \mu \mathrm{M}$ & $\begin{array}{c}289 \\
(191-438)\end{array}$ \\
\hline 18 & $\mathrm{C}_{6} \mathrm{H}_{5^{-}}\left(\mathrm{CH}_{2}\right)_{2^{-}}$ & $\begin{array}{c}189 \\
(176-203)\end{array}$ & $\begin{array}{c}24 \\
(13-44)\end{array}$ & $>100 \mu \mathrm{M}$ & $\begin{array}{c}86 \\
(42-173)\end{array}$ \\
\hline 13 & $\mathrm{C}_{6} \mathrm{H}_{5^{-}}\left(\mathrm{CH}_{2}\right)_{3^{-}}$ & $\begin{array}{c}264 \\
(204-342)\end{array}$ & $\begin{array}{c}1,640 \\
(1,500-1.810)\end{array}$ & $>100 \mu \mathrm{M}$ & $\begin{array}{c}568 \\
(463-696)\end{array}$ \\
\hline 19 & $\mathrm{C}_{6} \mathrm{H}_{5^{-}}\left(\mathrm{CH}_{2}\right)_{3^{-}}$ & $\begin{array}{c}466 \\
(365-594) \\
\end{array}$ & $\begin{array}{c}1,020 \\
(887-1,180) \\
\end{array}$ & $>100 \mu \mathrm{M}$ & $\begin{array}{c}523 \\
(353-774) \\
\end{array}$ \\
\hline
\end{tabular}

${ }^{\text {a }}$ Displacement of specific $\left[{ }^{3} \mathrm{H}\right] \mathrm{CCPA}$ binding in $\mathrm{CHO}$ cells, stably transfected with human recombinant $A_{1}$ adenosine receptor, expressed as $K_{i}(n M) .{ }^{b}$ Displacement of specific $\left[{ }^{3} H\right] N E C A$ binding in $\mathrm{CHO}$ cells, stably transfected with human recombinant $\mathrm{A}_{2 \mathrm{~A}}$ adenosine receptor, expressed as $\mathrm{K}_{\mathrm{i}}(\mathrm{nM}) .{ }^{\mathrm{c}}$ Measurement of receptor-stimulated adenylyl cyclase activity in $\mathrm{CHO}$ cells, stably transfected with human recombinant $\mathrm{A}_{2 \mathrm{~B}}$ adenosine receptor, expressed as $\mathrm{EC}_{50}$ (nM). ${ }^{\mathrm{d}}$ Displacement of specific $\left[{ }^{3} \mathrm{H}\right]$ NECA binding in $\mathrm{CHO}$ cells, stably transfected with human recombinant $\mathrm{A}_{3}$ adenosine receptor, expressed as $\mathrm{K}_{\mathrm{i}}(\mathrm{nM})$. 
The receptor-stimulated adenylyl cyclase activity expressed as $\mathrm{EC}_{50}$, nM. NECA (2), CGS 21680 (3), HENECA (4), and PHPNECA (5) were reported as reference compounds and the results are shown in Table $2 .{ }^{17}$

The reference compound NECA (2) showed high affinity at $A_{1}, A_{2 A}$, and $A_{3}$ receptors and was slightly $A_{3}$ selective $\left(K_{i} A_{1}=14 \mathrm{nM}, K_{i} A_{2 A}=20 \mathrm{nM}\right.$, and $\left.K_{i} A_{3}=6.2 \mathrm{nM}\right)$. The potency for $\mathrm{A}_{2 \mathrm{~B}}$ receptor, in the low micromolar range, characterized NECA as one of the most active nucleoside at this subtype $\left(\mathrm{EC}_{50} \mathrm{~A}_{2 \mathrm{~B}}=2,400 \mathrm{nM}\right)$.

The introduction of a 4-(2-carboxyethyl)phenylethylamino group in 2-position of NECA resulted in a compound, CGS 21680 (3), which showed decreased affinity and potency at $\mathrm{A}_{1}, \mathrm{~A}_{3}$, and $\mathrm{A}_{2 \mathrm{~B}}$ adenosine receptor subtypes, while its affinity at the $\mathrm{A}_{2 \mathrm{~A}}$ receptors was comparable to that of NECA, hence resulting $\mathrm{A}_{2 \mathrm{~A}}$ selective $\left[\mathrm{K}_{\mathrm{i}} \mathrm{A}_{1}=290 \mathrm{nM}, \mathrm{K}_{\mathrm{i}} \mathrm{A}_{2 \mathrm{~A}}=27 \mathrm{nM}, \mathrm{EC}_{50} \mathrm{~A}_{2 \mathrm{~B}}=89\right.$ $\mu \mathrm{M}$, and $\left.\mathrm{K}_{\mathrm{i}} \mathrm{A}_{3}=67 \mathrm{nM}\right]$. On the other hand, the presence of alkynyl chains in 2-position of NECA (compounds 4 and 5) resulted in improved $\mathrm{A}_{2 \mathrm{~A}}$ affinity compared to NECA and CGS 21680 [HENECA (4) and PHPNECA(5), $\mathrm{K}_{\mathrm{i}} \mathrm{A}_{2 \mathrm{~A}}=6.4 \mathrm{nM}$, and $\mathrm{K}_{\mathrm{i}} \mathrm{A}_{2 \mathrm{~A}}=3.1 \mathrm{nM}$, respectively, $v \mathrm{~s}$ NECA (2) and CGS 21680 (3), $\mathrm{K}_{\mathrm{i}} \mathrm{A}_{2 \mathrm{~A}}=20 \mathrm{nM}$, and $\mathrm{K}_{\mathrm{i}} \mathrm{A}_{2 \mathrm{~A}}=27 \mathrm{nM}$, respectively]. However, the increasing of $\mathrm{A}_{2 \mathrm{~A}}$ affinity was characterized by a contemporary increase of the $\mathrm{A}_{3}$ affinity, thus the two compounds were slightly $\mathrm{A}_{3}$ selective as NECA itself. In particular, PHPNECA was found to be a very potent agonist at all adenosine receptor subtypes and one of the most potent $\mathrm{A}_{2 \mathrm{~B}}$ agonist reported so far $\left(5, \mathrm{~K}_{\mathrm{i}} \mathrm{A}_{1}=2.7 \mathrm{nM}, \mathrm{K}_{\mathrm{i}} \mathrm{A}_{2 \mathrm{~A}}=3.1 \mathrm{nM}, \mathrm{EC}_{50} \mathrm{~A}_{2 \mathrm{~B}}=1,100 \mathrm{nM}\right.$, and $\mathrm{K}_{\mathrm{i}}$ $\left.\mathrm{A}_{3}=0.42 \mathrm{nM}\right){ }^{18}$

The 2-(aryl)alkylthio derivatives of adenosine and NECA (compounds 7-13 and 15-19, respectively) showed affinity at $A_{1}, A_{2 A}$, and $A_{3}$ adenosine receptor subtypes ranging from low $\mathrm{nM}$ to low $\mu \mathrm{M}$ value. On the contrary, functional data demonstrated that they did not activate the $\mathrm{A}_{2 \mathrm{~B}}$ receptors; in fact all the compounds possessed an $\mathrm{EC}_{50} \mathrm{~A}_{2 \mathrm{~B}}>100 \mu \mathrm{M}$.

Surprisingly, many compounds $(7,8,10,13,19)$ showed slight selectivity for the $A_{1}$ receptor, a subtype that is known to be activated preferentially by $\mathrm{N}^{6}$-substituted adenosine derivatives; the most potent was the 2-(1-pentyl)thioadenosine (7) with a $\mathrm{K}_{\mathrm{i}} \mathrm{A}_{1}=91 \mathrm{nM}$. The affinity of the corresponding NECA derivatives $\mathbf{1 5}$ decreased at all adenosine receptor subtypes, but these data are to be evaluated with caution because of problems of compound solubility. Substitution of the methyl of the 2-alkylthio chain in compound 7 with an hydroxyl group (compound 8) decreased affinity at all receptors.

It is worthwhile to note that only three compounds $(9,12,18)$ bound selectively the $A_{2 A}$ receptor subtype; thus, both in adenosine and in NECA series, the presence in 2-position of a phenylethylthio substituent was useful in order to improve $\mathrm{A}_{2 \mathrm{~A}}$ affinity. In fact, the 2phenylethylthioadenosine (12) and the 2-phenylethylthioNECA (18) were the most active $\mathrm{A}_{2 \mathrm{~A}}$ agonists with a $\mathrm{K}_{\mathrm{i}} \mathrm{A}_{2 \mathrm{~A}}=85 \mathrm{nM}$ and $24 \mathrm{nM}$, respectively. Once again, as in the case of CGS 21680, the presence of a particular substituent in the 2-position of NECA led to a compound which showed decreased affinity and potency at both $A_{1}, A_{3}$, and $A_{2 B}$ adenosine receptor subtypes, while maintaining a $\mathrm{A}_{2 \mathrm{~A}}$ affinity comparable to that of NECA, hence resulting in $\mathrm{A}_{2 \mathrm{~A}}$ selectivity. 
On the other hand, the presence of a longer chain (phenylpropylthio) led to two derivatives, compounds 13 and 19, which activated preferentially the $A_{1}$ receptors, while a shorter chain is better accommodated by the $\mathrm{A}_{3}$ receptor subtype; in fact the 2-phenylmethylthioadenosine (11) and the 2-phenylmethylthioNECA (17) were $\mathrm{A}_{3}$ selective and compounds 11 was the most active $\mathrm{A}_{3}$ agonist among the two series with a $\mathrm{K}_{\mathrm{i}} \mathrm{A}_{3}=68 \mathrm{nM}$.

On the contrary, when the phenyl ring is directly linked to the sulfur atom the corresponding adenosine and NECA derivatives (compounds 10 and 16, respectively) showed a different profile of activity; thus the 2-phenylthioadenosine was slightly $\mathrm{A}_{1}$ selective, while the corresponding NECA derivatives 16 was $\mathrm{A}_{3}$ selective.

In conclusion, although the preference for the different adenosine receptor subtypes seems do not clearly depend on the nature of the substituent present in the two position, in all cases the 2(aryl)alkylthioadenosine derivatives are more potent than the corresponding NECA derivatives at $\mathrm{A}_{1}$ receptors, ${ }^{19}$ while the NECA derivatives possess higher affinity in comparison with adenosines at both $\mathrm{A}_{2 \mathrm{~A}}$ and $\mathrm{A}_{3}$ receptors, with the exception of compound $\mathbf{1 7}$ which is less active than the corresponding adenosine derivative $\mathbf{1 1}$ at $\mathrm{A}_{3}$ receptor subtypes.

\section{Conclusions}

Biological data obtained with the two series of adenosine and NECA derivatives demonstrated that it is possible to modulate the activity at the $A_{1}, A_{2 A}$, and $A_{3}$ adenosine receptor subtypes by introducing different (aryl)alkylthio substituents in the 2-position of adenosine and NECA. In fact the best compounds emerging from this study, 2-(1-pentyl)thioadenosine (7) with a $\mathrm{K}_{\mathrm{i}} \mathrm{A}_{1}=$ $91 \mathrm{nM}$, 2-phenylethylthioNECA (18) with a $\mathrm{K}_{\mathrm{i}} \mathrm{A}_{2 \mathrm{~A}}=24 \mathrm{nM}$, and the 2phenylmethylthioadenosine (11) with a $\mathrm{K}_{\mathrm{i}} \mathrm{A}_{3}=68 \mathrm{nM}$, could be useful tools to be modificated in order to find very potent and selective agonists for the human adenosine receptor subtypes.

\section{Experimental Section}

General Procedures. Melting points were determined with a Büchi apparatus and are uncorrected. ${ }^{1} \mathrm{H}$ NMR spectra were obtained with Varian VXR $300 \mathrm{MHz}$ spectrometer; $\partial$ in ppm, $J$ in Hz. TLC were carried out on pre-coated TLC plates with silica gel 60 F-254 (Merck). For column chromatography, silica gel 60 (Merck) was used. Elemental analyses were determined on Carlo Erba model 1106 analyser and are within $\pm 0.4 \%$ of theoretical values.

\section{Preparation of 2-(aryl)alkylthioadenosines (7-13)}

A mixture of 2-iodoadenosine $(6,0.2 \mathrm{~g}, 0.51 \mathrm{mmol})^{13}$ in $5 \mathrm{~mL}$ of dry DMF, $2.55 \mathrm{mmol}$ of the appropriate mercaptan, and solid $\mathrm{K}_{2} \mathrm{CO}_{3}(150 \mathrm{mg}, 1.05 \mathrm{mmol})$ was heated in a steel bomb at $120{ }^{\circ} \mathrm{C}$ for the time reported in Table 1 . The reaction mixture was concentrated in vacuo and the residue was chromatographed on a silica gel column eluting with the suitable mixture of solvents (Table 1) to give 7-13 as chromatographically pure white powders. 
2-(1-Pentyl)thioadenosine (7). ${ }^{1} \mathrm{H}$ NMR $\left(\mathrm{Me}_{2} \mathrm{SO}-\mathrm{d}_{6}\right) \partial 0.89\left(\mathrm{t}, 3 \mathrm{H}, \mathrm{J}=6.6 \mathrm{~Hz}, \mathrm{CH}_{2} \mathrm{CH}_{3}\right), 1.35$ (m, 4H, $\left.\left(\mathrm{CH}_{2}\right)_{2} \mathrm{CH}_{3}\right), 1.65\left(\mathrm{~m}, 2 \mathrm{H}, \mathrm{CH}_{2} \mathrm{CH}_{2} \mathrm{~S}\right), 3.04\left(\mathrm{~m}, 2 \mathrm{H}, \mathrm{CH}_{2} \mathrm{~S}\right), 3.60\left(\mathrm{~m}, 2 \mathrm{H}, \mathrm{CH}_{2}-5\right.$ '), 3.92 (m, 1H, H-4'), 4.13 (m, 1H, H-3'), 4.62 (m, 1H, H-2'), 5.82 (d, 1H, J = 5.1 Hz, H-1'), 7.38 (bs,

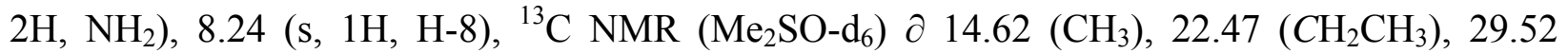
$\left(\mathrm{CH}_{2} \mathrm{CH}_{2} \mathrm{CH}_{3}\right), 30.74\left(\mathrm{CH}_{2} \mathrm{CH}_{2} \mathrm{~S}\right), 31.23\left(\mathrm{CH}_{2} \mathrm{~S}\right), 62.30$ (C-5'), 71.16 (C-3'), 73.84 (C-2'), 86.09 (C-4'), 88.02 (C-1'), 117.60 (C-5), 139.51 (C-8), 150.80 (C-4), 156.19 (C-2), 164.47 (C-6). Anal. Calcd. for $\mathrm{C}_{15} \mathrm{H}_{23} \mathrm{~N}_{5} \mathrm{O}_{4} \mathrm{~S}$ (369.4): C, 48.77; H, 6.28; N, 18.96. Found: C, 48.65; H, 6.15; N, 19.08 .

2-(1-Butyl-4-hydroxy)thioadenosine (8). ${ }^{1} \mathrm{H}$ NMR $\left(\mathrm{Me}_{2} \mathrm{SO}-\mathrm{d}_{6}\right) \partial 1.66\left(\mathrm{~m}, 4 \mathrm{H},\left(\mathrm{CH}_{2}\right)_{2} \mathrm{CH}_{2} \mathrm{~S}\right)$, $3.11\left(\mathrm{~m}, 2 \mathrm{H}, \mathrm{CH}_{2} \mathrm{~S}\right), 3.54\left(\mathrm{~m}, 4 \mathrm{H}, \mathrm{CH}_{2}-5^{\prime}\right.$ and $\left.\mathrm{CH}_{2} \mathrm{OH}\right), 3.92\left(\mathrm{~m}, 1 \mathrm{H}, \mathrm{H}-4^{\prime}\right), 4.15$ (m 1H, H-3'), $4.44\left(\mathrm{~m}, 1 \mathrm{H}, \mathrm{CH}_{2} \mathrm{OH}\right), 4.62$ (m, 1H, H-2'), 5.83 (d, J = 5.1 Hz, 1H, H-1'), 7.37 (bs, 2H, NH$)_{2}$, 8.24 (s, 1H, H-8). Anal. Calcd. for $\mathrm{C}_{14} \mathrm{H}_{21} \mathrm{~N}_{5} \mathrm{O}_{5} \mathrm{~S}$ (371.4): C, 45.27; H, 5.70; N, 18.86. Found: C, 45.08; H, 5.39; N, 18.98.

2-Cyclopentylthioadenosine (9). ${ }^{1} \mathrm{H}$ NMR $\left(\mathrm{Me}_{2} \mathrm{SO}-\mathrm{d}_{6}\right)$ D 1.60 (m, 6H, cyclopentyl), 2.15 (m, 2H, cyclopentyl), 3.57 (m, 2H, $\mathrm{CH}_{2}-5$ '), 3.92 (m, 2H, H-4' and CHS), 4.12 (m 1H, H-3'), 4.64 (m, 1H, H-2'), 5.82 (d, J=5.9 Hz, 1H, H-1'), 7.36 (bs, 2H, NH ), 8.24 (s, 1H, H-8). Anal. Calcd. for $\mathrm{C}_{15} \mathrm{H}_{21} \mathrm{~N}_{5} \mathrm{O}_{4} \mathrm{~S}$ (367.4): C, 49.03; H, 5.76; N, 19.06. Found: C, 48.81; H, 5.46; N, 19.30 .

2-Phenylthioadenosine (10). ${ }^{1} \mathrm{H}$ NMR ( $\left.\mathrm{Me}_{2} \mathrm{SO}-\mathrm{d}_{6}\right)$ d 3.32 (m, 2H, $\mathrm{CH}_{2}-5$ '), 3.84 (m, 2H, H-4' and H-3'), 4.55 (m, 1H, H-2'), 5.67 (d, J = 6.1 Hz, 1H, H-1'), 7.45 (m, 5H, H-Ph and NH $\mathrm{NH}_{2}, 7.60$ (m, $2 \mathrm{H}, \mathrm{H}-\mathrm{Ph}), 8.24$ (s, $1 \mathrm{H}, \mathrm{H}-8)$. Anal. Calcd. for $\mathrm{C}_{16} \mathrm{H}_{17} \mathrm{~N}_{5} \mathrm{O}_{4} \mathrm{~S}$ (375.4): C, 51.19; H, 4.56; N, 18.66. Found: C, 51.02; H, 4.44; N, 18.75 .

2-Benzylthioadenosine (11). ${ }^{1} \mathrm{H} \mathrm{NMR}\left(\mathrm{Me}_{2} \mathrm{SO}-\mathrm{d}_{6}\right)$ O 3.60 (m, 2H, $\mathrm{CH}_{2}-5$ '), 3.93 (m, 1H, H-4'), 4.15 (m, 1H, H-3'), 4.38 (s, 2H, $\mathrm{CH}_{2} \mathrm{~S}$ ), 4.57 (m, 1H, H-2'), 5.88 (d, 1H, J = 6.1 Hz, H-1'), 7.30 $(\mathrm{m}, 3 \mathrm{H}, \mathrm{H}-\mathrm{Ph}), 7.46\left(\mathrm{~m}, 4 \mathrm{H}, \mathrm{H}-\mathrm{Ph}\right.$ and $\left.\mathrm{NH}_{2}\right), 8.27$ (s, 1H, H-8). Anal. Calcd. for $\mathrm{C}_{17} \mathrm{H}_{19} \mathrm{~N}_{5} \mathrm{O}_{4} \mathrm{~S}$ (389.4): C, 52.43; H, 4.92; N, 17.98. Found: C, 52.34; H, 4.76; N, 18.15.

2-(1-Ethyl-2-phenyl)thioadenosine (12). ${ }^{1} \mathrm{H}$ NMR $\left(\mathrm{Me}_{2} \mathrm{SO}-\mathrm{d}_{6}\right)$ 2 2.99 (m, 2H, $\left.\mathrm{CH}_{2} \mathrm{Ph}\right), 3.32$ (m, 2H, $\left.\mathrm{CH}_{2} \mathrm{~S}\right), 3.61$ (m, 2H, $\mathrm{CH}_{2} 5^{\prime}$ '), 3.96 (m, 1H, H-4'), 4.15 (m, 1H, H-3'), 4.62 (t, 1H, J = $\left.5.5 \mathrm{~Hz}, \mathrm{H}-2^{\prime}\right), 5.92$ (d, 1H, J = 6.1 Hz, H-1'), 7.30 (m, 5H, H-Ph), 7.45 (bs, 2H, NH $), 8.29$ (s, 1H, H-8), ${ }^{13} \mathrm{C}$ NMR ( $\left.\mathrm{Me}_{2} \mathrm{SO}-\mathrm{d}_{6}\right)$ O 34.35 ( $\left.\mathrm{CH}_{2} \mathrm{~S}-\right), 61.46$ (C-5'), 70.40 (C-3'), 73.50 (C-2'), 85.41 (C-4'), 87.26 (C-1'), 116.96 (C-5), 126.85 (C-Ph), 128.32 (C-Ph), 129.08 (C-Ph), 138.66 (C-8 and $\mathrm{C}-\mathrm{Ph}), 150.10$ (C-4), 155.53 (C-2), 163.19 (C-6). Anal. Calcd. for $\mathrm{C}_{18} \mathrm{H}_{21} \mathrm{~N}_{5} \mathrm{O}_{4} \mathrm{~S}$ (403.5): C, 53.59; H, 5.25; N, 17.36. Found: C, 53.27; H, 5.18; N, 17.48 .

2-(3-Phenyl-1-propyl)thioadenosine (13). ${ }^{1} \mathrm{H} \mathrm{NMR}\left(\mathrm{Me}_{2} \mathrm{SO}-\mathrm{d}_{6}\right) \partial \mathrm{d}$ ) $\left(\mathrm{m}, 2 \mathrm{H}, \mathrm{CH}_{2} \mathrm{CH}_{2} \mathrm{Ph}\right)$, 2.74 (t, $J=7.1 \mathrm{~Hz}, 2 \mathrm{H}, \mathrm{CH}_{2} \mathrm{Ph}$ ), 3.09 (m, 2H, CH $2 \mathrm{~S}$ ), 3.94 (m, 1H, H-4'), 4.16 (m, 1H, H-3'), 4.63 (m, 1H, H-2'), 5.84 (d, J=5.9 Hz, 1H, H-1'), 7.25 (m, 5H, H-Ph), 7.39 (bs, 2H, NH $), 8.25$ (s, 1H, H-8). Anal. Calcd. for $\mathrm{C}_{19} \mathrm{H}_{23} \mathrm{~N}_{5} \mathrm{O}_{4} \mathrm{~S}$ (417.5): C, 54.66; H, 5.55; N, 16.78. Found: C, 54.48; H, 5.37; N, 16.85 . 
Preparation of 5-(6-amino-2-(aryl)alkylthiopurin-9-yl)-3,4-dihydroxytetrahydro furan -2carboxylic acid ethylamides (15-19)

A mixture of 5-(6-amino-2-iodopurin-9-yl)-3,4-dihydroxytetrahydrofuran-2-carboxylic acid ethylamide (2-iodoNECA) $(14,0.15 \mathrm{~g}, 0.35 \mathrm{mmol})^{14}$ in $5 \mathrm{~mL}$ of dry DMF, $1.75 \mathrm{mmol}$ of the appropriate mercaptan, and solid $\mathrm{K}_{2} \mathrm{CO}_{3}(150 \mathrm{mg}, 1.05 \mathrm{mmol})$ was heated in a steel bomb at $120^{\circ} \mathrm{C}$ for the time reported in Table 1 . The reaction mixture was concentrated in vacuo and the residue was chromatographed on a silica gel column eluting with the suitable mixture of solvents (Table 1) to give 15-19 as chromatographically pure white powders.

5-(6-Amino-2-pentylsulfanylpurin-9-yl)-3,4-dihydroxytetrahydrofuran-2-carboxylic acid ethylamide (15). ${ }^{1} \mathrm{H}$ NMR $\left(\mathrm{Me}_{2} \mathrm{SO}-\mathrm{d}_{6}\right) \partial 0.89\left(\mathrm{t}, J=6.9 \mathrm{~Hz}, 3 \mathrm{H},\left(\mathrm{CH}_{2}\right)_{4} \mathrm{CH}_{3}\right), 1.04(\mathrm{t}, J=$ $\left.7.0 \mathrm{~Hz}, 3 \mathrm{H}, \mathrm{CH}_{2} \mathrm{CH}_{3}\right), 1.32\left(\mathrm{~m}, 4 \mathrm{H},\left(\mathrm{CH}_{2}\right)_{2} \mathrm{CH}_{3}\right), 1.67\left(\mathrm{~m}, 2 \mathrm{H}, \mathrm{CH}_{2} \mathrm{CH}_{2} \mathrm{~S}\right), 3.12\left(\mathrm{~m}, 4 \mathrm{H}, \mathrm{CH}_{2} \mathrm{CH}_{3}\right.$ and $\left.\mathrm{CH}_{2} \mathrm{~S}\right), 4.20$ (m, 1H, H-3'), 4.30 (s, 1H, H-4'), 4.72 (m, 1H, H-2'), 5.92 (d, J= 7.2 Hz, 1H, H-1'), 7.45 (bs, 2H, NH 2$), 8.24$ (t, $J=5.9 \mathrm{~Hz}, 1 \mathrm{H}, \mathrm{NH}), 8.33$ (s, 1H, H-8). Anal. Calcd. for $\mathrm{C}_{17} \mathrm{H}_{26} \mathrm{~N}_{6} \mathrm{O}_{4} \mathrm{~S}$ (410.5): C, 49.74; H, 6.38; N, 20.47. Found: C, 49.54; H, 6.38; N, 20.47.

5-(6-Amino-2-phenylsulfanylpurin-9-yl)-3,4-dihydroxytetrahydrofuran-2-carboxylic acid ethylamide (16). ${ }^{1} \mathrm{H} \mathrm{NMR}\left(\mathrm{Me}_{2} \mathrm{SO}-\mathrm{d}_{6}\right) \partial 1.04\left(\mathrm{t}, \mathrm{J}=7.1 \mathrm{~Hz}, 3 \mathrm{H}, \mathrm{CH}_{2} \mathrm{CH}_{3}\right), 3.18(\mathrm{~m}, 2 \mathrm{H}$, $\mathrm{CH}_{2} \mathrm{CH}_{3}$ ), 4.12 (m, 1H, H-3'), 4.27 (s 1H, H-4'), 4.65 (m, 1H, H-2'), 5.82 (d, J= $7.2 \mathrm{~Hz}, 1 \mathrm{H}, \mathrm{H}-$ 1'), 7.45 (m, 5H, H-Ph and $\left.\mathrm{NH}_{2}\right), 7.58(\mathrm{~m}, 2 \mathrm{H}, \mathrm{H}-\mathrm{Ph}), 8.14(\mathrm{t}, J=5.9 \mathrm{~Hz}, 1 \mathrm{H}, \mathrm{NH}), 8.37$ (s, 1H, $\mathrm{H}-8$ ). Anal. Calcd. for $\mathrm{C}_{18} \mathrm{H}_{20} \mathrm{~N}_{6} \mathrm{O}_{4} \mathrm{~S}$ (416.5): C, 51.91; H, 4.84; N, 20.18. Found: C, 51.63; H, $4.56 ; \mathrm{N}, 20.54$.

5-(6-Amino-2-benzylsulfanylpurin-9-yl)-3,4-dihydroxytetrahydrofuran-2-carboxylic acid ethylamide (17). ${ }^{1} \mathrm{H}$ NMR $\left(\mathrm{Me}_{2} \mathrm{SO}-\mathrm{d}_{6}\right) \partial 1.02\left(\mathrm{t}, \mathrm{J}=6.8 \mathrm{~Hz}, 3 \mathrm{H}, \mathrm{CH}_{2} \mathrm{CH}_{3}\right), 3.19(\mathrm{~m}, 2 \mathrm{H}$, $\mathrm{CH}_{2} \mathrm{CH}_{3}$ ), 4.18 (m, 1H, H-3'), 4.31 (s 1H, H-4'), 4.38 (s, 2H, $\left.\mathrm{CH}_{2}-\mathrm{S}\right), 4.64$ (m, 1H, H-2'), 5.96 (d, $J=6.7 \mathrm{~Hz}, 1 \mathrm{H}, \mathrm{H}-1$ ') 7.26 (m, 3H, H-Ph), 7.50 (m, 4H, H-Ph and $\left.\mathrm{NH}_{2}\right), 8.27$ (t, $J=5.4 \mathrm{~Hz}$, $1 \mathrm{H}, \mathrm{NH}), 8.36$ (s, 1H, H-8). Anal. Calcd. for $\mathrm{C}_{19} \mathrm{H}_{22} \mathrm{~N}_{6} \mathrm{O}_{4} \mathrm{~S}(430.5) \mathrm{C}, 53.01 ; \mathrm{H}, 5.15 ; \mathrm{N}, 19.52$. Found: C, 52.75; H, 4.95; N, 19.87.

5-(6-Amino-2-phenethylsulfanylpurin-9-yl)-3,4-dihydroxytetrahydrofuran-2-carboxylic acid ethylamide (18). ${ }^{1} \mathrm{H}$ NMR $\left(\mathrm{Me}_{2} \mathrm{SO}-\mathrm{d}_{6}\right) \partial 1.03\left(\mathrm{t}, \mathrm{J}=7.0 \mathrm{~Hz}, 3 \mathrm{H}, \mathrm{CH}_{2} \mathrm{CH}_{3}\right), 2.97(\mathrm{~m}, 2 \mathrm{H}$, $\mathrm{CH}_{2} \mathrm{Ph}$ ), 3.10-3.50 (m, 4H, $\mathrm{CH}_{2} \mathrm{CH}_{3}$ and $\left.\mathrm{CH}_{2} \mathrm{~S}\right), 4.19$ (m, 1H, H-3'), 4.32 (s, 1H, H-4'), 4.70 (m, 1H, H-2'), 5.98 (d, J=7.0 Hz, 1H, H-1'), 7.39 (m, 5H, H-Ph), 7.50 (bs, 2H, NH 2$), 8.26$ (t, $J=$ $5.8 \mathrm{~Hz}, 1 \mathrm{H}, \mathrm{NH}), 8.36$ (s, 1H, H-8), ${ }^{13} \mathrm{C} \mathrm{NMR}\left(\mathrm{Me}_{2} \mathrm{SO}-\mathrm{d}_{6}\right) \partial 14.74\left(\mathrm{CH}_{3}\right), 31.87,33.37,35.59$ $\left(\mathrm{CH}_{2} \mathrm{~N}, \mathrm{CH}_{2} \mathrm{Ph}\right.$ and $\left.\mathrm{CH}_{2} \mathrm{~S}\right), 72.47,73.01$ (C-2' and C-3'), 84.17 (C-4'), 86.95 (C-1'), 117.07 (C5), 126.15 (C-Ph), 128.36 (C-Ph), 128.72 (C-Ph), 139.14, 140.58 (C-Ph and C-8), 150.34 (C-4), 155.64 (C-2), 163.48 (C-6), 169.13 (CO). Anal. Calcd. for $\mathrm{C}_{20} \mathrm{H}_{24} \mathrm{~N}_{6} \mathrm{O}_{4} \mathrm{~S}$ (444.5): C, 54.04; $\mathrm{H}$, 5.44; N, 18.91. Found: C, 53.79; H, 5.22; N, 19.17.

5-[6-Amino-2-(3-phenylpropylsulfanyl)purin-9-yl]-3,4-dihydroxytetrahydrofuran-2carboxylic acid ethylamide (19). ${ }^{1} \mathrm{H} \mathrm{NMR}\left(\mathrm{Me}_{2} \mathrm{SO}-\mathrm{d}_{6}\right) \partial 1.05\left(\mathrm{t}, \mathrm{J}=7.1 \mathrm{~Hz}, 3 \mathrm{H}, \mathrm{CH}_{2} \mathrm{CH}_{3}\right), 1.97$ $\left(\mathrm{m}, 2 \mathrm{H}, \mathrm{CH}_{2} \mathrm{CH}_{2} \mathrm{Ph}\right), 2.73\left(\mathrm{~m}, 2 \mathrm{H}, \mathrm{CH}_{2} \mathrm{Ph}\right), 2.97-3.34\left(\mathrm{~m}, 4 \mathrm{H}, \mathrm{CH}_{2} \mathrm{CH}_{3}\right.$ and $\left.\mathrm{CH}_{2} \mathrm{~S}\right), 4.23(\mathrm{~m}, 1 \mathrm{H}$, H-3'), 4.32 (s, 1H, H-4'), 4.62 (m, 1H, H-2'), 5.94 (d, J = 7.2 Hz, 1H, H-1'), 7.28 (m, 5H, H-Ph), 7.45 (bs, $\left.2 \mathrm{H}, \mathrm{NH}_{2}\right), 8.25(\mathrm{t}, J=5.7 \mathrm{~Hz}, 1 \mathrm{H}, \mathrm{NH}), 8.34(\mathrm{~s}, 1 \mathrm{H}, \mathrm{H}-8)$. Anal. Calcd. for $\mathrm{C}_{21} \mathrm{H}_{26} \mathrm{~N}_{6} \mathrm{O}_{4} \mathrm{~S}$ (458.5): C, 55.01; H, 5.72; N, 18.33. Found: C, 54.65; H, 5.49; N, 18.66. 


\section{Biological studies}

Cloning of the human adenosine receptors, stable transfection of cells, cell culture, membrane preparation, radioligand binding, and adenylyl cyclase activity have been fully described elsewhere. ${ }^{20}$ Briefly, all human subtypes were stably transfected into Chinese hamster ovary (CHO) cells in order to be able to study their pharmacological profile in an identical cellular background utilizing radioligand binding studies $\left(\mathrm{A}_{1}, \mathrm{~A}_{2 \mathrm{~A}}, \mathrm{~A}_{3}\right)$ or adenylyl cyclase activity assays $\left(\mathrm{A}_{2 \mathrm{~B}}\right)$.

Receptor binding affinity was determined using $\left[{ }^{3} \mathrm{H}\right] \mathrm{CCPA}$ as radioligand at $\mathrm{A}_{1}$ receptors, whereas $\left[{ }^{3} \mathrm{H}\right] \mathrm{NECA}$ was used at $\mathrm{A}_{2 \mathrm{~A}}$ and $\mathrm{A}_{3}$ subtypes. The procedure was performed as described previously. Due to the lack of a suitable radioligand the relative potency of agonists at $\mathrm{A}_{2 \mathrm{~B}}$ adenosine receptors was determined in adenylyl cyclase experiments. The procedure was carried out as described previously with minor modifications. ${ }^{20}$

\section{Acknowledgements}

Supported by a grant from the Ministry of Research (COFIN, Grant no. 200061553, 2002) and by the European Community (COST action no. D13/0009/00).

\section{References}

1. Adenosine Receptors: Medicinal Chemistry, Pharmacology and Therapeutic Applications; Cristalli, G.; Volpini R. Eds; Curr. Topics Med. Chem. 2003, 3, pp 355-469.

2. Yan, L.; Burbiel, J. C.; Maab, A.; Mueller, C. E. Expert Opin. Emerging Drugs 2003, 8, 537.

3. Jacobson, M. A. Expert Opin. Ther. Patents 2002, 12, 489.

4. Fredholm, B.; IJzerman, A. P.; Jacobson, K. A.; Klotz, K.-N.; Linden, J. Pharmacol. Rev. 2001, 53, 527.

5. Fredholm, B. B.; Cunha, R. A.; Svenningson, P. Curr. Topics Med. Chem. 2003, 3, 413.

6. Ha, S. B.; Nair, V. Tetrahedron Lett. 1996, 37, 1567.

7. Cristalli, G.; Lambertucci, C.; Taffi, S.; Vittori, S.; Volpini, R. Curr. Topics Med. Chem. 2003, 3, 387.

8. Maguire, H.; Nobbs, D. M.; Einstein, R.; Middleton, J. C. J. Med. Chem. 1971, 14, 415.

9. Marumoto, R.; Yoshioka, Y.; Osamu, M.; Shunsuke, S.; Imai, K.-I.; Kawazoe, K.; Honjo, M. Chem. Pharm. Bull. 1975, 23, 759.

10. Kikugawa, K.; Suehiro, H.; Ichino, M. J. Med. Chem. 1973, 16, 1381.

11. Kikugawa, K.; Suehiro, H.; Yanase, R.; Aoki, A. Chem. Pharm. Bull. 1977, 25, 1969.

12. Kikugawa, K.; Suehiro, H. J. Carb. Nucl. Nucl. 1975, 2, 159.

13. Nair, V.; Richardson, S. G. Synthesis 1982, 670. 
14. Cristalli, G.; Eleuteri, A.; Vittori, S.; Volpini, R.; Lohse, M. J.; Klotz, K.-N. J. Med. Chem. 1992, 35, 2363.

15. Cristalli, G.; Volpini, R.; Vittori, S.; Camaioni, E.; Monopoli, A.; Conti, A.; Dionisotti, S.; Zocchi, C.; Ongini, E. J. Med. Chem. 1994, 37, 1720.

16. Cristalli, G.; Volpini, R.; Vittori, S.; Camaioni, E.; Monopoli, A.; Conti, A.; Dionisotti, S.; Zocchi, C.; Ongini, E. J. Med. Chem. 1995, 37, 1720.

17. Klotz, K.-N.; Camaioni, E.; Volpini, R.; Kachler, S.; Vittori, S.; Cristalli, G. NaunynSchmiedeberg's Arch. Pharmacol. 1999, 360, 103.

18. Camaioni, E.; Di Francesco, E.; Vittori, S.; Volpini, R.; Cristalli, G. Bioorg \& Med Chem. 1997, 5, 2267.

19. Volpini, R.; Costanzi, S.; Lambertucci, C.; Taffi, S.; Vittori, S.; Klotz, K.-N.; Cristalli, G. J. Med. Chem. 2002, 45, 3271.

20. Klotz, K.-N.; Hessling, J.; Hegler J.; Owman, B.; Kull, B.; Fredholm, B. B.; Lohse M. J. Naunyn-Schmiedeberg's Arch. Pharmacol. 1998, 357, 1. 